\title{
The Development of Interactive Learning Multimedia Based on Problem Based Learning on Software Engineering Skills Competencies in SMK
}

\author{
Theodora Helena Hutagalung
}

Balai Besar Pengembangan Penjaminan Mutu Pendidikan Vokasi Bidang Bangunan dan Listrik, Medan, Indonesia Corresponding author. Email: theodorahelena@instruktur.belajar.id

\begin{abstract}
This development research aims to produce a product in the form of interactive learning multimedia based on problem-based learning that is feasible and effective for students of software engineering skill competencies in vocational high school (SMK). The research was conducted on a limited scale. In this study seven of the ten stages of development of Borg and Gall were carried out, which ended with a product effectiveness test. Development is divided into five stages: the preliminary research stage, the design stage, the product development stage, the review stage and product testing, and effectiveness testing. The data were collected through expert validation instruments and media acceptance instruments by students as well as instruments for student learning outcomes. 1) The results of the assessment / validation of product feasibility by media, learning design, and material / content experts show that the average percentage of eligibility is 87.4 while the results of the assessment / acceptance of multimedia by respondents (students) in individual and in groups trials have the average percentage of eligibility by 86.7 . In conclusion, the developed learning multimedia is in the very feasible criteria. 2) The results of the multimedia learning effectiveness test show the use of interactive multimedia learning based on Problem Based Learning has a significant effect on the learning outcomes of students who are taught using the media. This can be concluded from the results of research data processing in which tcount $=3.701$ with ttable $=1.679$ at the significant level $\alpha=0.05$. Because tcount $>$ ttable means that the interactive learning multimedia that is developed is able to improve the learning outcomes of software engineering skill competencies in vocational high school SMK, especially in Basic Programming subjects.
\end{abstract}

Keywords: Interactive learning multimedia, Problem-based learning, Software engineering.

\section{INTRODUCTION}

Development aims to develop quality resources, including human resources. As an internal part of development, the educational process cannot be separated from the development process itself. In vocational education, the ultimate goal is alumni to have standard of competence required by the world of work. The government set one jargon for vocational students: BMW, which is abbreviation for Bekerja (work), Melanjut (Going to college/university), Wirausaha (Entrepreneurship). To be able to compete and adapt to changes in the world of work, the students have to improve professional/technical competence and equip graduates with 21 st century skills.

From the structure of Curriculum 2013 for software engineering skills competencies, the subjects with the largest time allocation are programming-related subjects. Programming is a subject that was not studied at the previous level of education (elementary and junior high school). This lesson relies on programming logic and an understanding of the programming language used such as syntax, writing procedures, environment and others. Different programming languages used to build applications, can be different environments, syntax and writing procedures. Likewise, with how to run (Run) and form applications (Build). Basic Programming equips students with the ability to think logically and systematically about how to make an effective and efficient program. Programming subjects (Basic Programming, Object Oriented Programming, Web Programming, and Mobile Programming) all require hands-on practice on computers.

Several methods are widely used in teaching programming, such as: algorithmic oriented, language oriented, instructional oriented, and model oriented. These methods generally use coding elements such as assignments, expressions, reading, writing, operators, 
branching, iterations, procedures, functions, modules and others. On the other hand, coding is done according to the rules and environment of the programming language used. Error detection often provides certain difficulties for those who are just learning programming [1].

Some recommended teaching strategies to overcome challenges in teaching programming, such as: contextual tasks, collaborative learning, computational thinking development and programming tasks. These strategies are linked to active teaching and learning approaches, and can be combined to not only promote student engagement but also to deepen knowledge and understanding[2].

Computer programming without artificial intelligence (AI), provides output according to what is programmed. If there is a variable that does not match the algorithm, the program cannot provide output. Programs with AI are much smarter, can provide output by giving suggestions to the problems at hand. In the era of the industrial revolution 4.0 where AI plays an important role, the 21 st century skills framework is important for students to have. Students' critical thinking skills are one of the internal factors in the success of the teaching and learning process. In critical thinking skills students are expected to make rational decisions about what to do and what to believe.

The results of observations and interviews conducted, in general teacher of Basic Programming for Class X using learning media in the form of module materials with direct instruction learning models. This learning model consists of five stages of activities: orientation, presentation, structured practice, practice under guidance, and independent practice. Begins with the teacher determining the material, learning objectives and work procedures, linking them to the previous material. Next, the teacher presents the new knowledge and skills, explains the characteristics and gives examples. This stage is followed by structured practice and the teacher conducts guidance. Furthermore, giving students free time to learn the material, the teacher monitors students' work, evaluates students' abilities, and provides feedback on the day's lessons [3].

Problem-based Learning (PBL) is an active learning approach that is student-centered, and uses one or more problems as a learning tool. This approach enhances both technical and non-technical skills to solve them through teamwork and collaboration. One of the characteristics of PBL that supports its use in teaching computer science is to start learning with a problem [4]. With PBL students learn by tackling unclear and openended problems and reflecting on their experiences, thereby developing problem-solving strategies and building domain knowledge independently. It is important to incorporate a problem-solving approach to enable students to acquire critical thinking, creativity, teamwork and presentation skills, and to create a learning environment in which they engage in content and processes [5].

Based on the learning problems described above, to improve the quality of learning, to engage students in learning, especially on software engineering skill competency in SMK, it is necessary to conduct research and development of Interactive Learning Multimedia Based on Problem Based Learning. For this reason, the title of this research is: "The Development of Interactive Learning Multimedia Based on Problem Based Learning on Software Engineering Skills Competencies in SMK".

\section{THEORETICAL FRAMEWORK}

\subsection{Programming}

Software Engineering is Skill Competency in the Computer and Informatics Engineering Expertise Program. According to the 2013 Curriculum (K13) structure, programming-related subjects receive the largest time allocation. Basic Programming equips students with the ability to think logically and systematically about how to make an effective and efficient program. These subjects become the basis and support for mastery of programming subjects in the next semesters, namely Object Oriented Programming and Web and Mobile Programming [6].

Programming material includes concepts, procedures and problem solving skills through programming. To make a program, first master the basics of a programming language which includes the concepts, properties, functions of each menu and the commands that exist in the programming language. In addition, it requires a logical flow of rational and systematic thinking, the ability to understand the problem and find the most effective and efficient way to solve the problem. The problem solving method is then used as a reference for making programs using the rules of the programming language used. This means that to learn a programming language is not as simple as learning about facts, simple procedures or practical skills as learning computer program packages such as word processing, data processing and so on, but requires mastery of complex concepts and adequate cognitive strategies.

\subsection{Problem Based Learning (PBL)}

PBL was developed based on the constructivist paradigm, emphasizing students to actively construct their own knowledge through the problems they experience [7]. In the lesson plan, problems are designed that require students to gain important knowledge, make them proficient in solving problems, and have their own learning strategies and participate in teams. The learning process uses a systematic approach 
to solve problems or face challenges that are later needed in everyday life.

The characteristics of the PBL method are: learning begins with the provision of floating problems related to real life; problems are selected according to the learning objectives; students solve problems with authentic inquiry; together in small groups, students look for solutions to solve the problems given; teachers act as tutors and facilitators; students are responsible for obtaining varied knowledge and information, not from only one source; students present the results of problem solving in the form of certain products. In this case, the product is a program [8].

PBL based on Information and Communication Technology (ICT) must adapt the strategy to local conditions, educational goals, and traditional culture to overcome the constraints of human resources (HR) in using ICT [9]. Whereas the use of ICT-based PBL strategies that are carried out properly will be able to support successful learning [10], as well as contribute to achieving the desired learning outcomes [11].

\subsection{Interactive Learning Media}

Learning media are everything that is used to channel messages and can stimulate the thoughts, feelings, attention, and willingness of the learner so that it can encourage learning process, purposeful, and controlled [12]. In the context of learning media, media is not just information and its tools, but also the process of learning it, understanding the subject matter. In supporting this multimedia learning, multimedia instructional messages are designed in such a way as to support the achievement of learning objectives. A multimedia instructional message is a communication that uses words and pictures with the aim of enhancing learning [13]. In this sense there are 3 important parts, namely messages, instructional and multimedia. Messages reflect the idea of communication between teachers and students. Instructional reflects the learning objectives. Meanwhile, multimedia reflects the idea of using words and pictures in the presentation of learning materials. Multimedia message design is based on cognitive theory of how humans learn, especially multimedia-based learning. Multimedia forces the user to interact with the media and its content. This interaction varies because the user can select the material to be studied, move the desired page, or can enter answers from the exercise then the computer responds by providing work and discussion through feedback. Interactive learning multimedia has a positive effect in improving student learning outcomes [14-15].

\section{RESEARCH AND DEVELOPMENT METHOD}

\subsection{Design of Research and Development}

This research and development was carried out on class X students at SMK Brigjen Katamso in Medan in the even semester of the 2020/2021 school year.

The development procedure in this study was adapted from the Borg and Gall development model [16]. The scope of the research was carried out on a small scale with limited funds, from the ten stages of Borg and Gall development, this research carried out to the seventh stage which ended with testing the effectiveness of the product. The development is divided into five stages: preliminary research stage, design stage, product development stage, product review and testing stage, and effectiveness test.

The preliminary research stage was carried out to collect information by means of classroom observations and interviewing teachers and students. Based on the results of observations, the teacher applies direct learning using the media module with the stages: conveying objectives and preparing students, the teacher demonstrates knowledge or skills, conducts guided exercises, analyzes understanding and provides feedback; and provide opportunities for independent practice.

At the time of observation, learning activities tend to be less effective and less interesting. Subject teachers admit that students tend to be passive in learning activities. The results of interviews with several students showed that students considered basic programming lessons to be difficult subjects, due to the limitations of modules and teaching materials and the lack of media that supported basic programming learning to help students understand. Students consider basic programming lessons delivered with an introduction to theory in modules without a real picture, sometimes confusing, especially during independent learning. A common confusion is that during practice, one-character error gives rise to several massage errors.

Based on the results of the preliminary research, an interactive learning multimedia development plan was prepared, both learning planning and product planning. Together with the teacher, the learning needs, curriculum, and student characteristics are studied. Then the title, goals, objectives and main points of the material that will be included in the interactive learning multimedia are determined. Then a flowchart and storyboard are made, collecting materials and determining the application to be used.

In this step, all the materials that have been collected are integrated in a file which will later become a learning medium. The work is carried out according to 
the flowchart and storyboard that has been prepared previously.

After the product is produced, initial validation is carried out by experts (multimedia design, learning design, material/content). Revisions are carried out if there are suggestions/improvements for improvement, for further individual small group trials of 3 students of class X SMKS Brigjend Katamso Medan. The results of the trial were used as a source for the second revision, for further small group trials consisting of 9 students of class X of the same school. Next, based on small group input, appropriate revisions are made to the design so that the product meets the needs and goals set.

In the last stage, activities aimed at knowing the effectiveness of the developed interactive learning media products were carried out. The revised interactive learning media was re-tested in a larger group, namely 30 students of class X SMKS Brigjend Katamso Medan. At this stage, there were two groups who took the Basic Programming lesson on the KD 3.7 topic. and 4.7. about Looping in Programming, where the first group learns using the developed media and the second group learns without the developed media.

\subsection{Instrument}

In this study, two types of instruments were used, including: questionnaires for validation of learning design experts, media and materials as well as acceptance of learning multimedia and learning outcomes instruments. The validation questionnaire aims to obtain media validation based on the compiled instrument grid and the opinions of related experts [17]. The effectiveness of student learning outcomes is measured by learning outcomes tests. The learning outcomes test consists of a number of test items that are arranged based on the learning objectives in the lesson plan (RPP). The questions are built in the form of multiple choice by applying higher-order thinking levels referring to Bloom's revised taxonomy of thinking processes [18].

\subsection{Data Analysis}

In this study, three data analysis techniques were used. Qualitative descriptive analysis techniques were used when processing data from the validation instruments of experts and acceptance of learning multimedia. Quantitative descriptive statistical techniques are used to process the numerical data obtained into a descriptive percentage form. Third, in testing the research hypothesis, inferential statistical analysis (t-test) was used.

\section{RESULT AND DISCUSSION}

\subsection{Product}

The final product of the development is in the form of problem-based interactive learning multimedia with KD 3.7 material. and 4.7 about looping in programming. This final result was obtained after going through the stages of validation and testing. The product is packaged in the form of a $\mathrm{CD}$, distributed to teachers and students in groups who use media when learning. The purpose of developing this product is as a learning medium as well as a tool for students to learn independently but also to develop the nature of student creativity and collaboration.

After learning, in both groups evaluation was carried out after learning, so that the results of the effectiveness of the interactive learning multimedia developed were obtained.

\subsection{Result of Product Feasibility Test}

Based on the results of expert validation (learning multimedia design, learning design, and content), the results obtained are as in the table below:

Table 1: Average Expert Validation Results in percentage

\begin{tabular}{|l|l|l|}
\hline Validator & Percentage & Criteria \\
\hline Multimedia Expert & $84,5 \%$ & Good \\
\hline Instructional Expert & $92,1 \%$ & Very Good \\
\hline Content Expert & $85,8 \%$ & Very Good \\
\hline
\end{tabular}

From the table 1 above, the average percentage is $87.4 \%$ (criteria: very good).

Multimedia acceptance by students is described in the table 2 below.

Table 2: Average Multimedia Acceptance by Students in Percentage

\begin{tabular}{|l|l|l|}
\hline Students & Percentage & Criteria \\
\hline Individual Trial & $86,0 \%$ & Very Good \\
\hline Small Group Trial & $87,0 \%$ & Very Good \\
\hline Field Group Trial & $87,2 \%$ & Very Good \\
\hline
\end{tabular}

The average acceptance of multimedia by students in percentage is $86.7 \%$ (very good criteria). The conclusion from the two results above is that the interactive learning multimedia developed is feasible to use. 


\subsection{Learning Outcomes}

Next is to see the effect of using learning multimedia, whether it provides a significant difference in results compared to using the module. The test was carried out with the t-test of student learning outcomes.

From the results of the calculation obtained the price of tcount $=3.701$ and table $=1.679$ at the significant level $\alpha=0.05$. By comparing the two, it is obtained that tcount $>$ ttable so that due to the use of interactive multimedia learning based on Problem Based Learning that was developed, there are differences in student learning outcomes. Student learning outcomes in the experimental class are greater than the learning outcomes of the control class, which means that the interactive multimedia learning developed is able to improve the learning outcomes of the SMK Software Engineering Competency Group, especially in Basic Programming subjects.

The use of interactive multimedia learning based on Problem Based Learning that was tested on class $\mathrm{X}$ students on the competence of Software Engineering at SMKS Brigjend Katamso Medan showed a positive and significant influence on learning outcomes, especially in mastering factual, conceptual, procedural knowledge and analyzing basic programming problems. The problem-based learning model is student-centered, which uses one or more problems as a learning tool to improve technical and non-technical skills in solving problems, through teamwork and collaboration. It demonstrates a problem-solving approach enabling students to acquire critical thinking, creativity, teamwork and presentation skills, and creates a learning environment in which they engage in content and process. With the PBL learning model and using interactive multimedia learning, students are equipped with 21 st century skills, namely critical thinking, creative, working together and communicating.

\section{CONCLUSION}

Multimedia learning according to its function can be used as the main learning media and as a companion in learning. Multimedia can be developed according to the characteristics of students to facilitate students with different types of learning.

Problem-based Learning (PBL) learning model is an active learning approach with a student-centered approach, which uses one or more problems as a learning tool, improving technical and non-technical skills to solve them, through teamwork and collaboration. With this learning model, students are equipped with $21 \mathrm{st}$ century skills, namely critical thinking, creative, working together and communicating.
Based on the conclusions of the research results and findings in the field, the development of interactive multimedia learning based on Problem Based Learning on Software Engineering skills competencies in SMK has high implications when used by teachers and students in learning. The interactive learning multimedia developed provides practical benefits, especially during the implementation of learning by the teacher, namely this learning multimedia can be an additional source of learning both during learning and when students study independently, so that students can repeat at any time without depending on the presence of the teacher. In other words, interactive multimedia learning can be used appropriately as an innovative and effective tool in a problem-based learning environment for the acquisition of problem solving skills, especially in the Software Engineering skills competencies in SMK.

\section{ACKNOWLEDGMENT}

I would like to express great appreciation to my thesis supervisors, R. Mursid and Sriadhi, for their valuable and constructive suggestions during the planning and development of this research work; and to examiner team for their valuable critiques. I would also like to thank the principal and the teachers of the school where the research took place, for their valuable technical support on the research. To my family, thank you for the support and encouragement.

\section{REFERENCES}

[1] P. Szlávi, L. Zsakó, Method of Teaching Program. University of Debrecen. DOI: 10.5485/TMCS.2003.0023., 2003.

[2] S. Sentence, A. Csizmadia, Computing in the curriculum: Challenges and strategies from a teacher's perspective. DOI: 10.1007/s10639-0169482-0, 2016.

[3] B. Joyce, M. Weil, Models of Teaching, New Jersey: Prentice-Hall, 1980

[4] A.MCA. Oliveira, SC dos Santos, V.C. Garcia, PBL in Teaching Computing: An Overview of the Last $15 \quad$ Years, 2013. DOI: 10.1109/FIE.2013.6684830.

[5] M. Neo, T.K. Neo, Multimedia Learning: Using Multimedia as a platform for instruction and learning in higher education, Multimedia University International Symposium on Information and Communication Technologies 2000 (M2USIC'2000), PJ Hilton, October 5-6, 2000, PP S3-1.1 - 1.4.

[6] Perdirjen No 07/D.D5/KK/2018, Vocational High School Curriculum Structure (Struktur Kurikulum SMK/MA), Dikdasmen Kemdikbud, 2018. 
[7] J.C. Dring, Problem-Based Learning Experiencing and Understanding the Prominence during Medical School: Perspective, in: Journal Annals of Medicine and Surgery 47, 2019. DOI: 10.1016/j.amsu.2019.09.004.

[8] O.S. Tan, Problem-Based Learning Innovation: Using Problems to Power Learning in the $21 \mathrm{st}$ Century, Gale Cengage Learning, Singapore, 2003, pp. 27-41.

[9] L. Dirckinck-Holmfeld, Innovation of Problem Based Learning through ICT: Linking Local and Global Experiences, in: International Journal of Education and Development using ICT (IJEDICT), 5(1):3-12, 2009.

[10] S.F.M. Yassin, S. Rahman, H. Yamat, Interdisciplinary Integration Through ProblemBased Learning with ICT in Pre-Service Teacher Education, in: Proceedings of EABR \& ETLC Conferenc, Dublin, Ireland, 2010, pp. 377-385.

[11] A.K.F. Ma, J. O’Toole, M. Kepple, An Investigation of Student Teachers Attitudes to the Use of Media Triggered Problem Based Learning, in: Australian Journal of Educational Techonology, 24(3): pp. 311-325, 2008

[12] Y. Miarso Yusufhadi, Sowing the Seeds of Educational Technology (Menyemai Benih Teknologi Pendidikan), Kencana Prenada Media Group, Jakarta, 2011.

[13] R.E. Mayer, Multimedia Learning, Prinsip-prinsip dan Aplikasi, Pustaka Pelajar, Yogyakarta, 2009.

[14] A.N. Saragih, A.H. Saragih, R. Mursid, Development of Interactive Learning Media in English Subjects (Pengembangan Media Pembelajaran Interaktif Pada Mata Pelajaran Bahasa Inggris), in: Journal TIK dalam Pendidikan, 5(2), 2018, pp.210-222.

[15] M. Arifin, R. Mursid, Development of Interactive Learning Media in Automotive Engineering Energy Conversion Machine Subjects (Pengembangan Media Pembelajaran Interaktif pada Mata Pelajaran Mesin Konversi Energi Teknik Otomotif), in: Jurnal Teknologi Informasi \& Komunikasi Dalam Pendidikan 5 (2), 2018, pp. 182-194.

[16] W.R. Borg, M.D. Gall. "Educational Research: An Introduction", Fifth Edition, Longman, New York, 1983.

[17] Sriadhi, Learning Multimedia Assessment Instruments (Instrumen Penilaian Multimedia Pembelajaran),

https://www.researchgate.net/publication/33458688

\section{9_INSTRUMEN_PENILAIAN _MULTIMEDIA_PEMBELAJARAN, 2019.}

[18] L.W. Anderson and Krathwohl, A Taxonomy for Learning, teaching, and AssessingL A Revision of Bloom's Taxonomy of Educational Objectives, Longman, New York, 2001. 